\title{
Fungal Peptic Ulcer Disease in an Immunocompetent Patient
}

\author{
Ridwaan Albeiruti ${ }^{1}$, Fahad Chaudhary ${ }^{1}$, Hiren Vallabh ${ }^{2}$, Troy Krupica ${ }^{1}$, Justin Kupec ${ }^{2}$ \\ ${ }^{1}$ Department of Medicine, West Virginia University, Morgantown, WV, USA \\ ${ }^{2}$ Section of Digestive Diseases, West Virginia University, Morgantown, WV, USA
}

Doi: 10.12890/2020_001696- European Journal of Case Reports in Internal Medicine - ○ EFIM 2020

Received: 29/04/2019

Accepted: 05/05/2020

Published: $21 / 05 / 2020$

How to cite this article: Albeiruti R, Chaudhary F, Vallabh H, Krupica T, Kupec J. Fungal peptic ulcer disease in an immunocompetent patient. EJCRIM 2020;7: doi:10.12890/2020_001696.

Conflicts of Interests: The Authors declare that there are no competing interests.

This article is licensed under a Commons Attribution Non-Commercial 4.0 License

\section{ABSTRACT}

The lifetime prevalence of peptic ulcer disease (PUD) is 5-10\%. While PUD in immunocompetent patients is most commonly associated with Helicobacter pylori infection or the use of non-steroidal anti-inflammatory drugs (NSAIDs), other common causes of PUD must also be considered in the differential diagnosis. We describe a case of endoscopic and histological resolution of PUD related to Candida infection in a healthy, immunocompetent woman.

\section{LEARNING POINTS}

- Peptic ulcer disease (PUD) can be secondary to fungal infections, even in immunocompetent patients.

- A higher index of suspicion needs to be maintained for fungal causes of PUD, particularly if symptoms do not improve.

- Recognizing fungal causes of PUD may lead to faster diagnosis and treatment.

\section{KEYWORDS}

Peptic ulcer disease, Candida infection

\section{CASE DESCRIPTION}

A 50-year-old woman presented with a 3-month history of post-prandial abdominal cramping, vomiting and a $7 \mathrm{lb}$ weight loss. Her medical history was significant for hypertension, hyperlipidaemia, depression, chronic obstructive pulmonary disease (COPD) and gastroesophageal reflux disease. There was no history of HIV (human immunodeficiency virus) or diabetes. She denied non-steroidal anti-inflammatory drug (NSAID) use and alcohol consumption and was not taking corticosteroids. Endoscopic evaluation was performed.

Esophagogastroduodenoscopy (EGD) revealed a $1 \mathrm{~cm}$, non-bleeding, irregular-shaped, deep and clean-based ulcer at the pylorus (Fig. 1). The remainder of the examination was unremarkable. Biopsies were taken and revealed an ulcer with necro-inflammatory debris and fungal organisms, consistent with Candida species (Fig. 2). Periodic acid-Schiff (PAS) fungal stain revealed scattered yeast colonizing the fibrinous debris (Fig. 3).

The patient was given a 3-week course of fluconazole and her symptoms had resolved on follow-up. Repeat EGD (2 months later) revealed resolution of her ulcer (Fig. 4). Repeat biopsies of the pylorus were negative for any evidence of fungal organisms (Fig. 5).

\section{DISCUSSION}

Peptic ulcers are breaks in the gastric or duodenal mucosa which penetrate through the muscularis mucosa and create a cavity with surrounding inflammation. Peptic ulcer disease (PUD) is the most common cause of stomach and duodenal perforation. Worldwide, there were 87.4 million new cases of peptic ulcers in 2015 resulting in 267,500 deaths ${ }^{[1]}$. PUD affects more than 6 million people in the USA each year $^{[2]}$. 

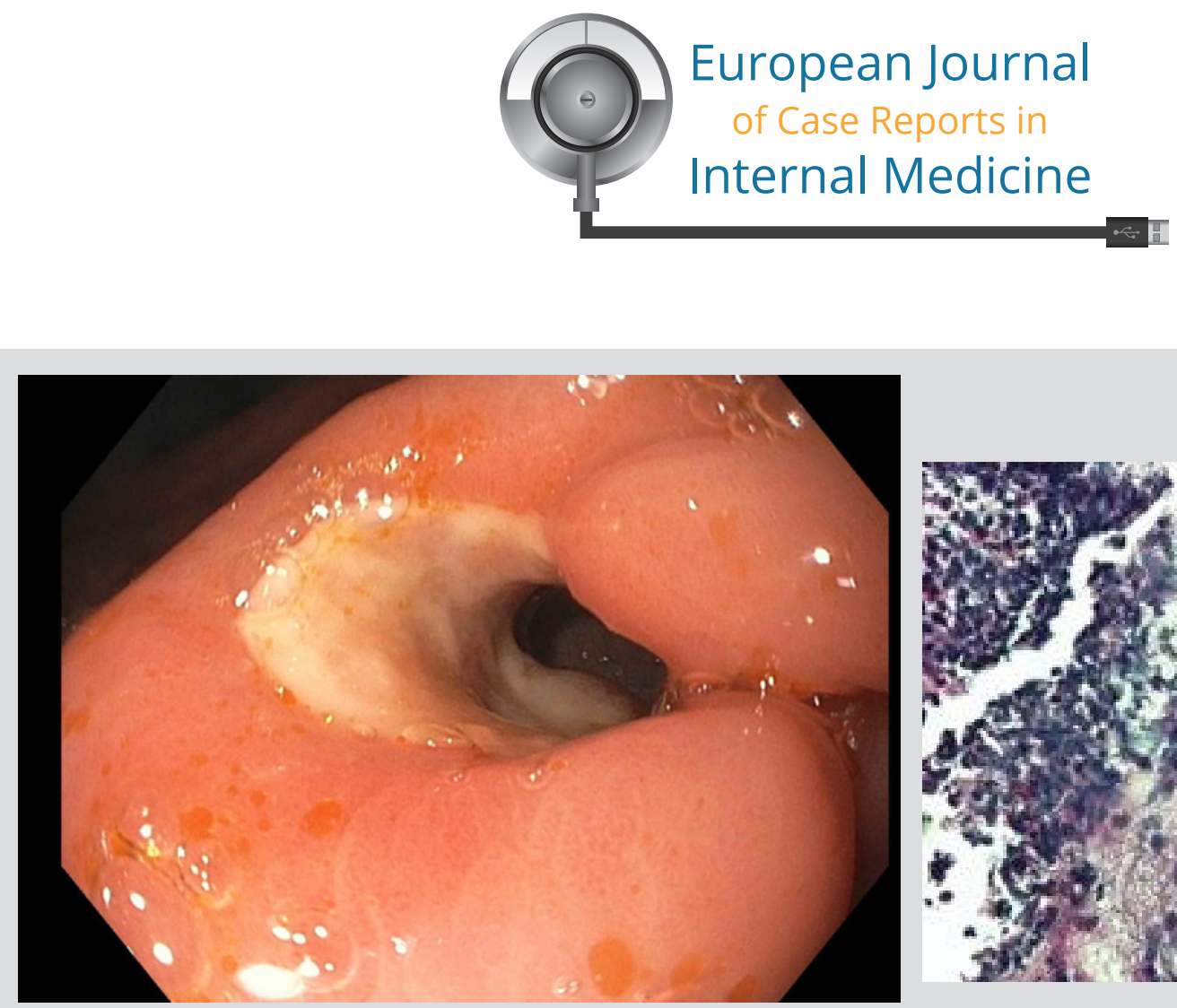

Figure 1. Initial endoscopy findings

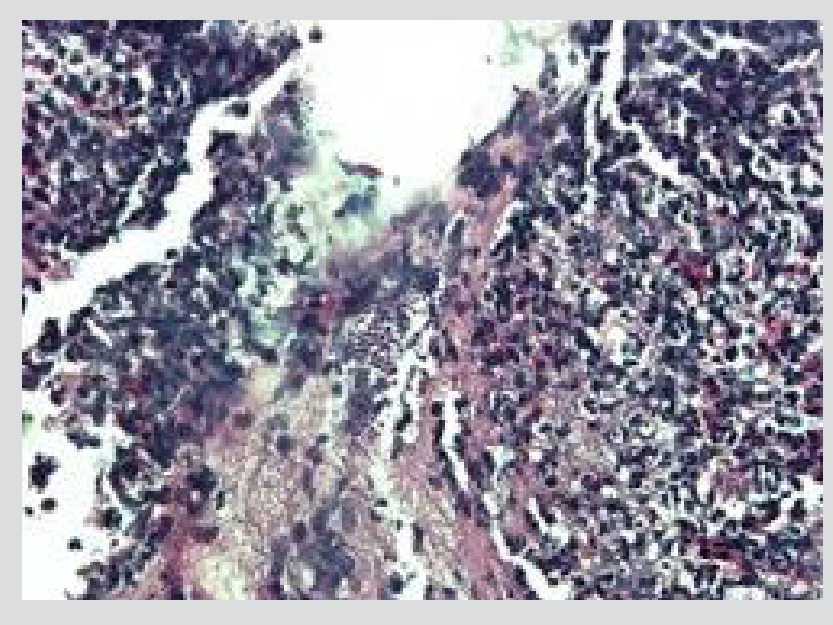

Figure 2.H\&E staining of biopsy specimen
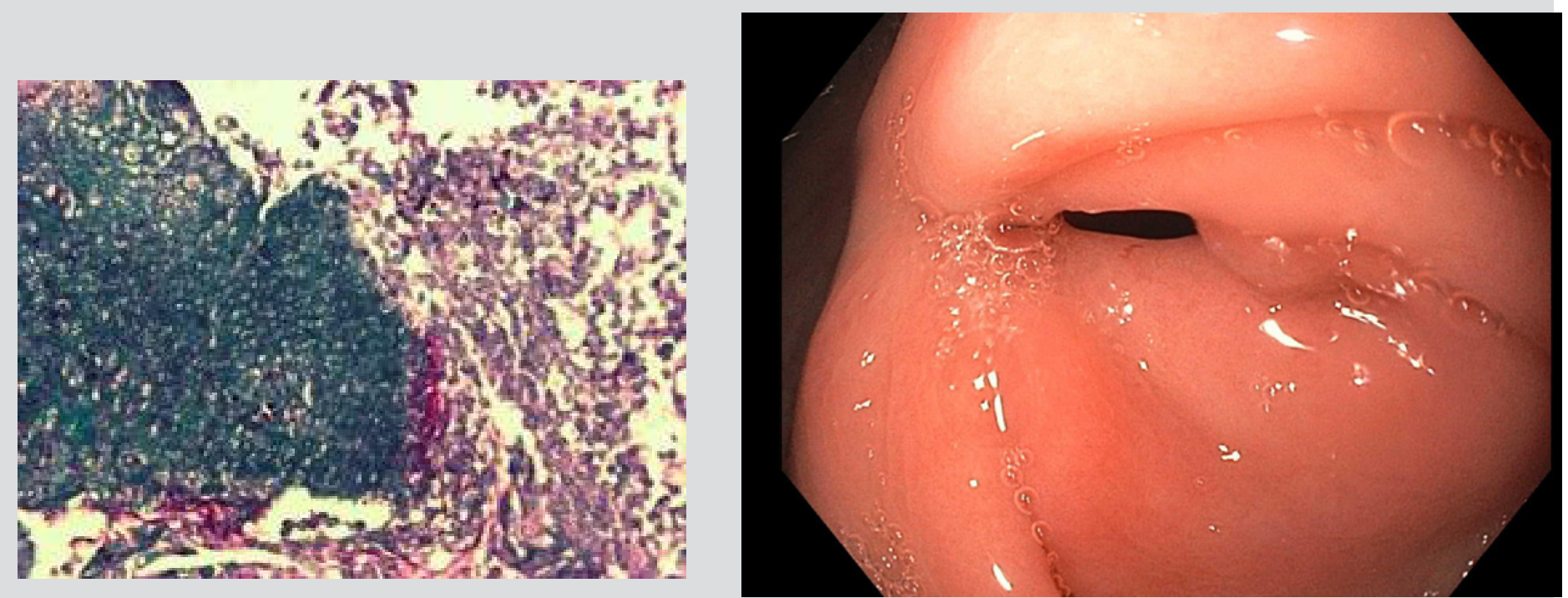

Figure 3. Periodic acid-Schiff (PAS) staining of biopsy specimen

Figure 4. Endoscopy after treatment

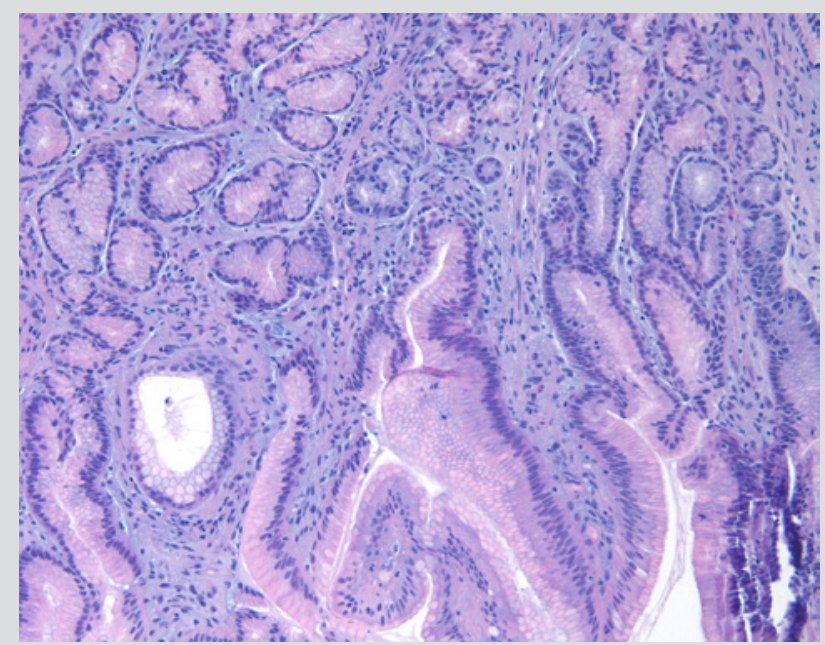

Figure 5. Repeat biopsy after treatment 
A large, retrospective study using the National Inpatient Sample consisting of US inpatient data between 1998 and 2005 showed an average annual PUD hospitalization rate of 63.6/100,000 population.

Helicobacter pylori infection and NSAID use are responsible for the overwhelming majority of PUD cases. However, improved detection with endoscopy has reduced H. pylori prevalence. Other causes of non-H. pylori non-NSAID ulcers include antiplatelet drugs, stress, Helicobacter heilmannii, cytomegalovirus, Behçet's disease, Zollinger-Ellison syndrome, Crohn's disease and cirrhosis with portal hypertension ${ }^{[3]}$. Risk factors for the development of PUD are the use of NSAIDs, H. pylori, COPD, chronic renal insufficiency and tobacco use. Even though fungal PUD has a prevalence of $4-36 \%$, the diagnosis is frequently overlooked ${ }^{[4]}$.

Candida is a normal commensal organism in the gut and colonizes the oesophagus in $20 \%$ of healthy adults ${ }^{[5]}$. Few cases of fungal PUD in immunocompetent patients have been reported over the past 10 years (Table 1). A review of 16 patients between 1998 and 2007 at a university hospital in Korea revealed that nine cases of gastric candidiasis were benign ulcers and the other seven were malignant. Similar to previous literature, associated conditions included diabetes, cirrhosis, lung cancer and pulmonary tuberculosis ${ }^{[6]}$.

A literature review yielded 10 cases of fungal PUD in immunocompetent patients with risk factors such as smoking, steroid use and heavy antacid use. Antifungal treatment resulted in clinical improvement and ulcer resolution in eight of the 10 patients. One patient, with a perforated fungal ulcer, died post-operatively after cardiac arrest and did not receive any medication. Another patient refused treatment and interestingly was found to have a recurrent Candida-associated gastric ulcer in a different location. One patient was found to have $\mathrm{H}$. pylori on an initial biopsy of a peptic ulcer, followed by Candida albicans on the second endoscopy. Two patients had co-existing infection with both $\mathrm{H}$. pylori and $\mathrm{C}$. albicans and were both successfully treated with an antifungal agent and a proton-pump inhibitor. Patients with large ulcers may have fungal PUD. Overall, the treatments were varied as regards lengths of treatment and antifungal agents which included fluconazole, caspofungin and amphotericin B (Table 1). Our patient eventually achieved clinical and biopsy-proven resolution after completing a course of fluconazole, providing more evidence for the use of antifungals in the treatment of Candida PUD.

\section{CONCLUSION}

We present a case of EGD and biopsy-proven resolution of PUD secondary to Candida infection in an immunocompetent patient. It is important for clinicians to maintain a higher index of suspicion for other causes of PUD for correct and prompt management. 


\begin{tabular}{|c|c|c|c|c|c|c|c|}
\hline & $\begin{array}{l}\text { Patient age, } \\
\text { gender }\end{array}$ & Presentation & Risk factors & Endoscopy & $\begin{array}{c}\text { Histopathology/ } \\
\text { culture }\end{array}$ & Treatment & Outcome \\
\hline Cascio et al, 2011 ${ }^{[7]}$ & $62, M$ & $\begin{array}{l}\text { Severe epigastric } \\
\text { pain }\end{array}$ & Heavy smoker & $\begin{array}{l}\text { None. Ex-lap with } \\
2.5 \mathrm{~cm} \text { wide } \\
\text { perforation of } \\
\text { duodenal bulb }\end{array}$ & $\begin{array}{l}\text { Candida krusei on } \\
\text { biopsy and peritoneal } \\
\text { fluid culture }\end{array}$ & Caspofungin & Resolution \\
\hline $\begin{array}{l}\text { Nishimura et al, } \\
2011^{[8]}\end{array}$ & $73, F$ & $\begin{array}{l}\text { Unknown } \\
\text { (article in Japanese) }\end{array}$ & None & $\begin{array}{l}\text { Two gastric ulcers } \\
\text { with thick exudates } \\
\text { in the fornix }\end{array}$ & $\begin{array}{l}\text { Numerous Candida } \\
\text { forms }\end{array}$ & Antifungal & Resolution \\
\hline $\begin{array}{l}\text { Nagata et al, } \\
2012^{[9]}\end{array}$ & $82, \mathrm{M}$ & Epigastric pain & None & $\begin{array}{l}\text { Ulcerous lesions } \\
\text { with thick exudates } \\
\text { in the fornix and } \\
\text { corpus and severe } \\
\text { atrophic gastritis }\end{array}$ & $\begin{array}{l}\text { Candida forms and } \\
\text { Helicobacter pylori } \\
\text { (confirmed with 13C } \\
\text { breath test) }\end{array}$ & $\begin{array}{l}\text { Antifungal and } \\
\text { PPI }\end{array}$ & Resolution \\
\hline Rai et al, 2012 $2^{[10]}$ & $25, F$ & $\begin{array}{l}\text { Upper abdominal } \\
\text { pain, cough, fever }\end{array}$ & None & $\begin{array}{l}\text { Oval to circular } \\
10 \times 6 \mathrm{~cm} \text { ulcer }\end{array}$ & $\begin{array}{l}\text { 1st EGD - H. pylori; } \\
\text { 2nd EDG - granulation } \\
\text { tissue, numerous } \\
\text { yeast and } \\
\text { pseudohyphae on PAS } \\
\text { consistent with } \\
\text { Candida albicans }\end{array}$ & $\begin{array}{l}\text { Amphotericin } \\
B+P P I\end{array}$ & $\begin{array}{l}\text { Survived; } \\
\text { following EGD } \\
\text { normal }\end{array}$ \\
\hline Sasaki, 2012 $2^{[11]}$ & $87, F$ & Anorexia & $\begin{array}{c}\text { Steroid inhaler use, } \\
\text { risedronate }\end{array}$ & $\begin{array}{l}\text { Medium-sized } \\
\text { submucosal } \\
\text { tumour-like } \\
\text { elevation covered } \\
\text { with erythematous } \\
\text { mucosa with an } \\
\text { oval, deep central } \\
\text { ulcer }\end{array}$ & $\begin{array}{l}\text { Large number of } \\
\text { hyphae; } \\
\text { Candida tropicalis } \\
\text { by culture }\end{array}$ & None & $\begin{array}{l}\text { Recurrent } \\
\text { Candida- } \\
\text { associated } \\
\text { gastric ulcer }\end{array}$ \\
\hline Gupta, $2012^{[12]}$ & $50, M$ & $\begin{array}{l}\text { Sudden onset } \\
\text { abdominal pain } \\
\text { and shock }\end{array}$ & $\begin{array}{l}\text { Strong antacid } \\
\text { intake }\end{array}$ & $\begin{array}{l}\text { None. } \\
\text { Ex-lap with } 1 \times 1 \mathrm{~cm} \\
\text { prepyloric } \\
\text { perforation }\end{array}$ & $\begin{array}{l}\text { Pseudohyphae, } \\
\text { suggestive of Candida; } \\
\text { peritoneal fluid } \\
\text { with C. albicans }\end{array}$ & $\begin{array}{l}\text { Not given } \\
\text { antifungal } \\
\text { treatment }\end{array}$ & $\begin{array}{l}\text { Died from } \\
\text { cardiac arrest }\end{array}$ \\
\hline Ince et al, 2014 & $55, M$ & $\begin{array}{l}\text { Haematemesis and } \\
\text { melena }\end{array}$ & None & $\begin{array}{l}\text { Giant gastric ulcer } \\
\text { (4 cm diameter) } \\
\text { with oozing } \\
\text { visible vessel on } \\
\text { yellow base in } \\
\text { corpus region }\end{array}$ & $\begin{array}{l}\text { H. pylori and positive } \\
\text { PAS; C. albicans } \\
\text { and Candida } \\
\text { kefyr growth }\end{array}$ & $\begin{array}{l}\text { Fluconazole } \\
400 \text { mg on 1st } \\
\text { day followed by } \\
200 \mathrm{mg} \text { daily } \\
\text { for } 2 \text { weeks and } \\
\text { esomeprazole } \\
\text { magnesium } \\
40 \mathrm{mg} \\
\text { for } 1 \text { month }\end{array}$ & $\begin{array}{l}\text { Almost complete } \\
\text { healing of ulcer } \\
\text { on 3-week followup } \\
\text { EGD. Eradication } \\
\text { of H. pylor } \\
\text { i afterwards }\end{array}$ \\
\hline $\begin{array}{l}\text { Ukekwe et al, } \\
2015^{[14]}\end{array}$ & $70, M$ & $\begin{array}{l}\text { Epigastric pain } \\
\text { followed by } \\
\text { abdominal } \\
\text { wall rigidity }\end{array}$ & None & $\begin{array}{l}\text { None. } \\
\text { Ex-lap revealed } \\
3.1 \times 1 \mathrm{~cm} \text { gastric } \\
\text { perforation covered } \\
\text { with fibrinous } \\
\text { exudate }\end{array}$ & $\begin{array}{l}\text { Candida growth } \\
\text { (numerous spores and } \\
\text { budding hyphae) }\end{array}$ & $\begin{array}{l}\text { Fluconazole, } \\
\text { clindamycin, } \\
\text { ciprofloxacin, } \\
\text { levofloxacin, } \\
\text { imipenem }\end{array}$ & Resolution \\
\hline Goyal et al, 2016 $6^{[15]}$ & $45, F$ & $\begin{array}{l}\text { Persistent } \\
\text { epigastric pain } \\
\text { and vomiting } \\
\text {, weight loss }\end{array}$ & NSAID use & $\begin{array}{l}\text { Circumferential } \\
\text { ulcer at pylorus } \\
\text { extending into } \\
\text { 1st part of } \\
\text { duodenum }\end{array}$ & $\begin{array}{l}\text { Fungal spores and } \\
\text { budding yeast forms } \\
\text { of Candida species }\end{array}$ & $\begin{array}{c}\text { Fluconazole } 200 \\
\text { mg for } 2 \\
\text { weeks }\end{array}$ & $\begin{array}{l}\text { Small healing } \\
\text { clean-based ulcer } \\
\text { on 1-month } \\
\text { follow-up EGD }\end{array}$ \\
\hline $\begin{array}{l}\text { Albeiruti, } 2020 \\
\text { (our case) }\end{array}$ & $50, F$ & $\begin{array}{l}\text { Post-prandial } \\
\text { abdominal pain, } \\
\text { vomiting, } \\
\text { weight loss }\end{array}$ & COPD & $\begin{array}{l}1 \mathrm{~cm} \text { irregular } \\
\text { shaped ulcer } \\
\text { at pylorus }\end{array}$ & $\begin{array}{l}\text { Necroinflammatory } \\
\text { debris and fungal } \\
\text { consistent with } \\
\text { Candida }\end{array}$ & Fluconazole & Resolution \\
\hline
\end{tabular}




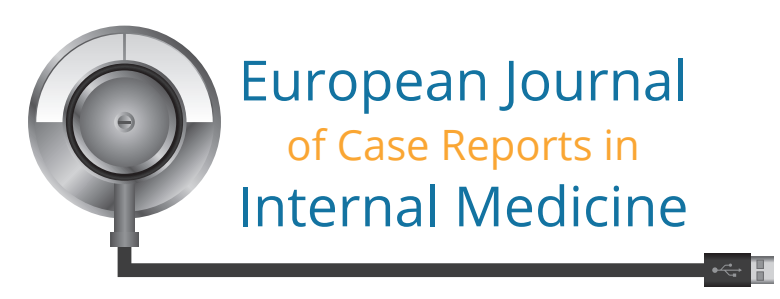

\section{REFERENCES}

1. GBD 2015 Disease and Injury Incidence and Prevalence Collaborators. Global, regional, and national incidence, prevalence, and years lived with disability for 310 diseases and injuries, 1990-2015: a systematic analysis for the Global Burden of Disease Study 2015. Lancet 2016;388(10053):1545-1602.

2. Sandler RS, Everhart JE, Donowitz M, et al. The burden of selected digestive diseases in the United States. Gastroenterology 2002;122(5):1500-1511.

3. Najm WI. Peptic ulcer disease. Prim Care 2011;38(3):383-194, vii.

4. Loffeld RJ, Loffeld BC, Arends JW, et al. Fungal colonization of gastric ulcers. Am J Gastroenterol 1988;83(7):730-733.

5. Vermeersch B, Rysselaere M, Dekeyser K, et al. Fungal colonization of the esophagus. Am J Gastroenterol 1989;84(9):1079-1083

6. Jung MK, Jeon SW, Cho CM, et al. Treatment of gastric candidiasis in patients with gastric ulcer disease: are antifungal agents necessary? Gut Liver 2009;3(1):31-34

7. Cascio A, Bartolotta M, Venneri A, et al. A case of Candida krusei peritonitis secondary to duodenal perforation due to Candida duodenitis. Mycopathologia 2011;171(1):51-5.

8. Nishimura S, Nagata N, Kobayakawa M, et al. A case of candidal infection of gastric ulcers with characteristic endoscopic findings. Nihon Shokakibyo Gakkai Zasshi 2011:108(8):1393-8.

9. Nagata N, Nakashima R, Nishimuira S. Candida associated gastric ulcers in an elderly patient. Intern Med 2012;51(11):1433.

10. Rai P, Chakraborty SB. Giant fungal gastric ulcer in an immunocompetent individual. Saudi J Gastroenterol 2012;18(4):282-4.

11. Sasaki K. Candida-associated gastric ulcer relapsing in a different position with a different appearance. World J Gastroenterol 2012;18(32):4450-3.

12. Gupta N. A rare cause of gastric perforation-Candida infection: a case report and review of the literature. J Clin Diagn Res 2012;6(9):1564-5.

13. Ince AT, Kocaman O, Ismailova M, et al. A rare co-existence of Helicobacter pylori, Candida albicans and Candida keyfr in a giant gastric ulcer. Turk J Gastroenterol 2014;25(4):4356.

14. Ukekwe FI, Nwajiobi C, Agbo MO, et al. Candidiasis, A Rare Cause of Gastric Perforation: A Case Report and Review of Literature. Ann Med Health Sci Res 2015;5(4):314-6.

15. Goyal P, Bansal S, Kaur P, et al. Candida associated giant non-healing gastric ulcer in an immunocompetent host. J Gastroenterol Liver Dis 2016;1(1):1003. 